Proc. Estonian Acad. Sci. Eng., 2005, 11, 3, 234-244

\title{
An algorithm of the formation of waste load in industrial effluents
}

\author{
Jüri Säärekõnno \\ Institute of Environmental Engineering, Tallinn University of Technology, Ehitajate tee 5, 19086 \\ Tallinn, Estonia; jsaarek@edu.ttu.ee \\ Received 11 May 2004, in revised form 3 March 2005 \\ Abstract. Nowadays industry is facing significant new challenges as the production processes must \\ become more sustainable. Therefore the environmental impact assessment is necessary for any \\ company. In this study an algorithm, describing the formation of the load of residue substances in \\ industrial effluents, is presented. The algorithm, expressed in the form of a limiting state equation, \\ enables assessment of the environmental impact either of the total effluent of the company (integral \\ level of analysis) or of one effluent from each water use unit (differential level). This analysis \\ represents a part of the wider (total) environmental impact assessment of the company that may be \\ carried out together with the product life cycle assessment.
}

Key words: industrial effluents, pollutant substances, waste load, modelling, limiting state equation, environmental impact assessment.

\section{INTRODUCTION}

By the second half of the 20th century the industrial activities had become so intensive, that environmental problems gained a great significance. Today all available indicators show that the quality of the environment is deteriorating seriously. At the global level, the greenhouse gas effect and the depletion of the ozone layer $\left[{ }^{1,2}\right]$ as well as the loss of habitats and species $\left[^{2,3}\right]$ must be mentioned. At a more local (regional) level, the pollution of watercourses and sea $\left[{ }^{4-6}\right]$, the decline in urban air quality $\left[{ }^{7,8}\right]$, the degradation of soil $\left[{ }^{8,9}\right]$ etc., are ubiquitous. There is a general consensus that the industry is the major source of environmental pollution $\left[{ }^{10,11}\right]$. Thus there exists a significant environmental challenge to industry - to minimize its environmental impact, i.e. the products and technological processes in which they are produced must become environmentally harmless. For an existing plant the first step is the assessment of its 
current environmental performance. The key performance areas of the internal environmental impact of the industry are the emissions to water and air, i.e. the issues characterizing the negative aspects of environmental performance. This study aims to analyse the environmental impact of industrial effluents (wastewater) as one of the main pollution sources to the natural waterbodies.

\section{MODELLING THE WATER USE}

For more detailed assessment of the environmental impact of the effluents from a company, there is a need to use an algorithm that describes the formation of the load of substances in the wastewater. This algorithm can be found for all the three main directions of water consumption (technological, auxiliarysubsidiary and domestic-potable). By dividing the total water consumption (flowoff) process into a number of components (unit processes), a clearer picture of the areas of inefficiency can be established. In this paper, two main schemes of industrial water consumption, direct and consecutive, are analysed. In the first case raw water is used in every separate operation, where water is needed, and is directed afterwards into the receiving waterbody or sewer without any treatment or after treatment. In case of consecutive water consumption, the same water is going through different unit operations one after another without or with intermediate treatment. On the basis of these two basic models it is possible to describe any other more or less combined water use system in an existing plant.

\section{ALGORITHM OF THE FORMATION OF THE POLLUTING LOAD}

There are three main directions of industrial water use: 1) technological (t), 2) auxiliary-subsidiary (a) and 3) domestic-potable (p). The water use process in each direction should be divided into a number of unit operations (processes) $v=i, j, k$, corresponding to the technological, auxiliary-subsidiary and domestic water consumption, respectively. The industrial flow-off $\left(q_{\mathrm{t}}, q_{\mathrm{a}}, q_{\mathrm{p}}\right)$ and its unit processes $\left(q_{\mathrm{t} i}, q_{\mathrm{aj}}, q_{\mathrm{p} k}\right)$, have the same specification. For a more rational estimation of the environmental impact of a company, an analytical method of the formation process of pollution substances (PS) according to the main directions of water use, would be expedient. In case of a direct system of water supply $\left[{ }^{12}\right]$ (Fig. 1a), the increased amount (mass) $\mathrm{M}^{+}$of a PS under consideration, occurring in industrial wastewater at a time unit ( $\mathrm{g} / \mathrm{h}$, for example), may be calculated by water-using unit operations (needs) according to the three main water use directions $\mathrm{t}$, a and $\mathrm{p}$ :

$$
M^{+}=\sum_{i=1}^{l} \Delta c_{i}^{+} q_{\mathrm{ti}}+\sum_{j=1}^{m} \Delta c_{j}^{+} q_{\mathrm{aj}}+\sum_{k=1}^{n} \Delta c_{k}^{+} q_{\mathrm{p} k}
$$


(a)

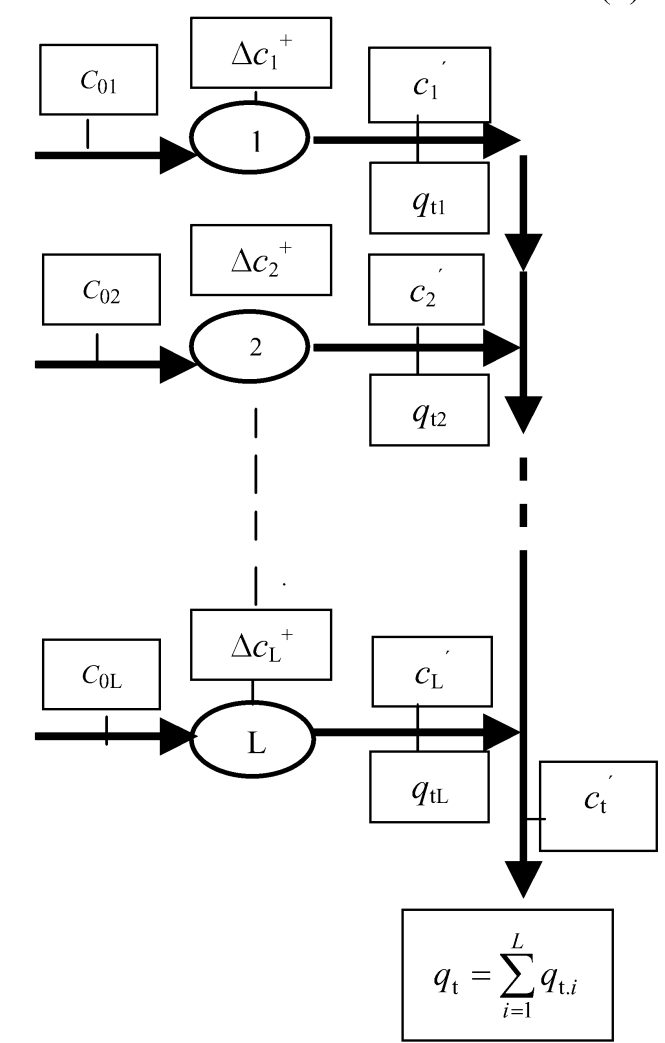

(b)
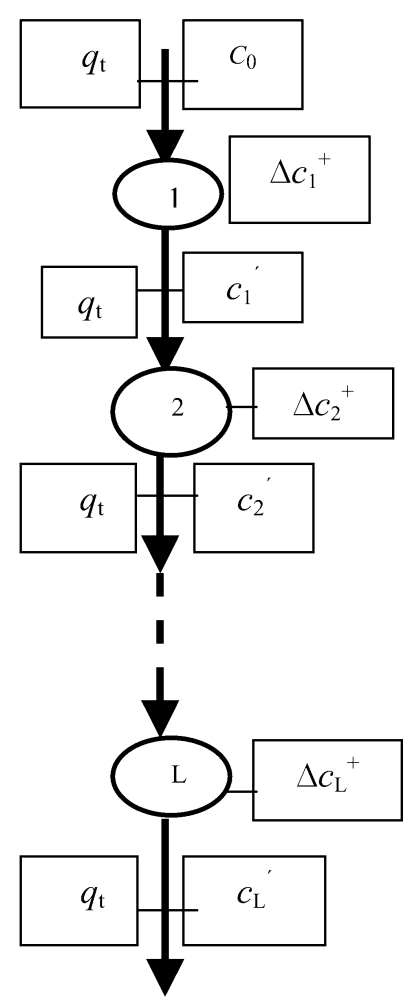

Fig. 1. The formation of wastewater and its parameters by water using unit operations of the technological water use: (a) direct system of water supply; (b) consecutive system of water supply.

where $\Delta c_{v}^{+}(v=i, j, k)$ is the increase in the concentration of PS during unit operations ( $l, m$ and $n$ denote total number of unit processes according to the water use directions $\mathrm{t}$, a and $\mathrm{p}$, respectively), $q_{\mathrm{ti}}, q_{\mathrm{aj}}$ and $q_{\mathrm{p} k}$ are flow-offs by unit operations $i, j, k$ of technological, auxiliary-subsidiary and domestic-potable water use directions, respectively.

The increase $\Delta c_{v}^{+}$in concentration of PS is determined as

$$
\Delta c_{v}^{+}=c_{v}^{\prime}-c_{0 v},
$$

where $c_{v}^{\prime}$ is concentration of PS in effluents after unit operations $v=i, j, k$ of the main three water use directions, respectively and $c_{0 v}$ is the background concentration of PS in the incoming water. Calculation according to Eq. (2) is carried out for getting rid of the influence of the harmful substances that get into the facility with the raw water and which influence the products of the facility. If the background value of $c_{0 v}$ is the same for all unit operations $v$, this value may 
be replaced by the concentration $c_{0}$ (Fig. 1a). In Eq. (2), when $c_{0 v} \rightarrow 0$ we have $\Delta c_{v}^{+}=c_{v}^{\prime}$. Thus Eq. (1) may be expressed as

$$
M^{+}=M=\sum_{i=1}^{l} c_{i}^{\prime} q_{\mathrm{t} i}+\sum_{j=1}^{m} c_{j}^{\prime} q_{\mathrm{aj}}+\sum_{k=1}^{n} c_{k}^{\prime} q_{\mathrm{p} k},
$$

where $c_{v}^{\prime}$ is the concentration of PS after each unit operation $v$.

If industrial wastewater from various unit operations $v$ undergoes in-plant treatment (Fig. 2), the concentration of PS in the treated wastewater is determined as

$$
c_{v}^{\prime \prime}=c_{v}^{\prime}\left(1-k_{v}\right),
$$

where $c_{v}^{\prime \prime}$ is the concentration of PS after in-plant treatment facility of unit operations and $k_{v}$ is the treatment coefficient of PS in treatment facilities of unit operations $v$. Decrease in the concentration of PS in wastewater treatment facilities (TF) in unit operations $v$ (Fig. 2) is:

$$
\Delta c_{v}^{-}=c_{v}^{\prime}-c_{v}^{\prime \prime}=c_{v}^{\prime}-c_{v}^{\prime}\left(1-k_{v}\right)=c_{v}^{\prime} k_{v} .
$$

Now the decrease in mass of PS in in-plant treatment facilities in a time unit is expressed (according to the three water use directions $t$, a and $\mathrm{p}$ ) as

$$
M^{-}=\sum_{i=1}^{l} \Delta c_{i}^{-} q_{\mathrm{ti}}+\sum_{j=1}^{m} \Delta c_{j}^{-} q_{\mathrm{aj}}+\sum_{k=1}^{n} \Delta c_{k}^{-} q_{\mathrm{p} k},
$$

where $\Delta c_{v}^{-}$is calculated from Eq. (5). Knowing the PS, generated in a production process $M^{+}$(Eq. (1)) and the portion of it, removed in the in-plant treatment facilities $M^{-}$(Eq. (6)), it is possible to determine the residue of PS at a time unit $(M)$ in the treated wastewater of the enterprise

$$
M=M^{+}-M^{-}=\sum_{i=1}^{l} \Delta c_{i} q_{\mathrm{ti}}+\sum_{j=1}^{m} \Delta c_{j} q_{\mathrm{aj}}+\sum_{k=1}^{n} \Delta c_{k} q_{\mathrm{pk}},
$$

where the concentration of PS in the treated wastewater after unit operations $v$ is

$$
\Delta c_{v}=\Delta c_{v}^{+}-\Delta c_{v}^{-}=c_{v}^{\prime \prime}-c_{0 v} .
$$

If $c_{0 v}<<c_{v}^{\prime \prime}$, the background pollution should be subtracted from Eq. (8) and Eq. (7) takes the form

$$
M=\sum_{i=1}^{l} c_{i}^{\prime \prime} q_{\mathrm{t} i}+\sum_{j=1}^{m} c_{j}^{\prime \prime} q_{\mathrm{a} j}+\sum_{k=1}^{n} c_{k}^{\prime \prime} q_{\mathrm{p} k}
$$

where the concentration $c_{v}^{\prime \prime}$ is determined by Eq. (4). 
(a)
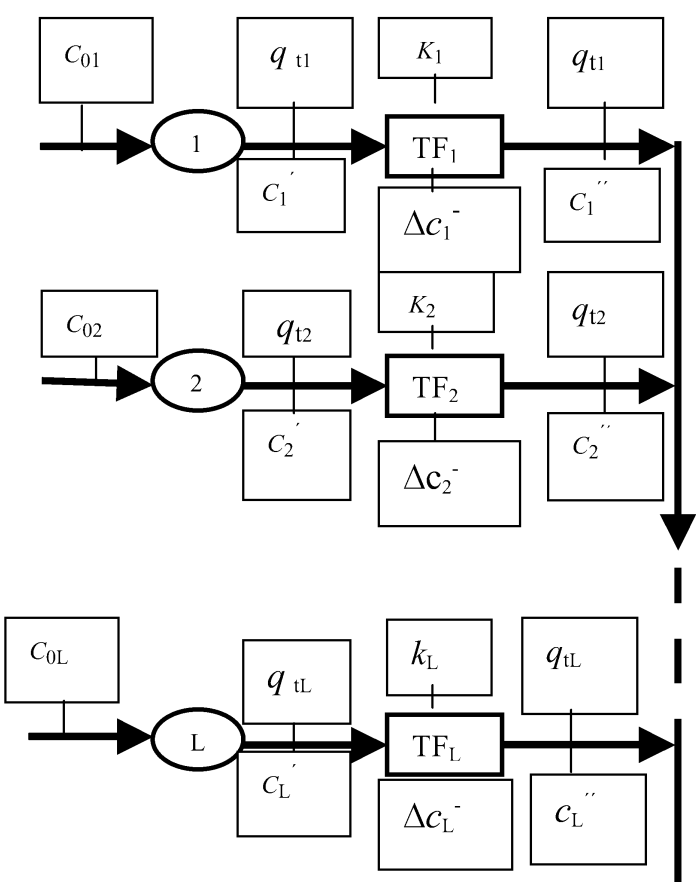

(b)
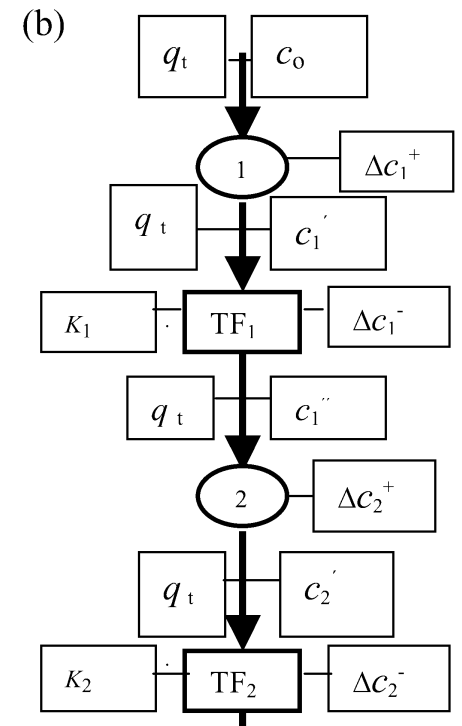

$q_{\mathrm{t}}$

$c_{2}$

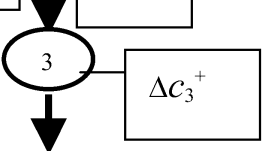

I
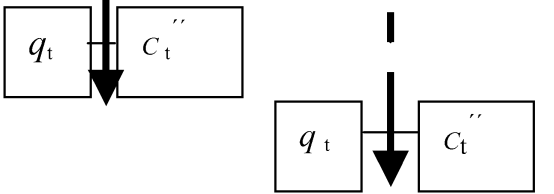

Fig. 2. The formation of wastewater and its treatment parameters by unit operations of the technological water use: (a) direct system of water supply; (b) consecutive system of water supply.

If the total effluent of the enterprise $q_{\mathrm{e}}$ is treated only in a common in-plant treatment facility and the water consumption system is direct, Eq. (3) takes the following form:

$$
M=\left(1-k_{\mathrm{e}}\right)\left(\sum_{i=1}^{l} c_{i}^{\prime} q_{\mathrm{t} i}+\sum_{j=1}^{m} c_{j}^{\prime} q_{\mathrm{aj}}+\sum_{k=1}^{n} c_{k}^{\prime} q_{\mathrm{p} k}\right)=c^{\prime \prime} q_{\mathrm{e}},
$$

where $k_{\mathrm{e}}$ is the treatment factor of PS at a common treatment facility of the plant and $c^{\prime \prime}$ is the concentration of PS in the total industrial effluent, treated in the common treatment facility.

The value of $q_{\mathrm{e}}$ may be calculated as

$$
q_{\mathrm{e}}=\sum_{i=1}^{l} q_{\mathrm{t} i}+\sum_{j=1}^{m} q_{\mathrm{a} j}+\sum_{k=1}^{n} q_{\mathrm{p} k}
$$


If the water consumption system is consecutive (Fig. 1b) and the total effluent of the enterprise is treated in the common in-plant treatment facility, the mass flow of PS may be calculated as

$$
M=\left(1-k_{\mathrm{e}}\right)\left(q_{\mathrm{t}} \sum_{i=1}^{l} c_{i}^{\prime}+q_{\mathrm{a}} \sum_{j=1}^{m} c_{j}^{\prime}+q_{\mathrm{p}} \sum_{k=1}^{n} c_{k}^{\prime}\right),
$$

where $q_{\mathrm{t}}, q_{\mathrm{a}}$ and $q_{\mathrm{p}}$ are wastewater flow rates according to the main directions of water consumption. In case of the consecutive system of water supply without effluent treatment after each separate operation (Fig. 1b), the increase of the pollutant load is

$$
M^{+}=q_{\mathrm{t}} \sum_{i=1}^{l} \Delta c_{i}^{+}+q_{\mathrm{a}} \sum_{j=1}^{m} \Delta c_{j}^{+}+q_{\mathrm{p}} \sum_{k=1}^{n} \Delta c_{k}^{+},
$$

where

$$
\begin{gathered}
\Delta c_{v}^{+}=c_{v}^{\prime}-c_{v-1}^{\prime} \quad \text { if } v=i, j, k \geq 2, \\
c_{v-1}^{\prime}=c_{0} \quad \text { and } \quad \Delta c_{v}^{+}=c_{v}^{\prime}-c_{0} \quad \text { if } v=i, j, k=1 .
\end{gathered}
$$

The mass of PS, removed in the in-plant treatment facility of unit operations $v$ in case of the consecutive system of water supply (Fig. 2b), is determined as

$$
M^{-}=q_{\mathrm{t}} \sum_{i=1}^{l} \Delta c_{i}^{-}+q_{\mathrm{a}} \sum_{j=1}^{m} \Delta c_{j}^{-}+q_{\mathrm{p}} \sum_{k=1}^{n} \Delta c_{k}^{-},
$$

where $\Delta c_{v}^{-}$is determined from Eq. (5). Now, from Eqs. (13) and (16) the residue of PS in a time unit in the treated wastewater is

$$
\begin{gathered}
M=M^{+}-M^{-} \\
=q_{\mathrm{t}}\left[\sum_{i=1}^{l}\left(\Delta c_{i}^{+}-\Delta c_{i}^{-}\right)\right]+q_{\mathrm{a}}\left[\sum_{j=1}^{m}\left(\Delta c_{j}^{+}-\Delta c_{j}^{-}\right)\right]+q_{\mathrm{p}}\left[\sum_{k=1}^{n}\left(\Delta c_{k}^{+}-\Delta c_{k}^{-}\right)\right],
\end{gathered}
$$

where $\Delta c_{v}^{+}$is calculated from Eq. (15) if $v=1$ and from Eq. (14) if $v \geq 2$. At the first unit operation $(v=1)$ it is possible to write:

$$
\Delta c_{1}^{+}-\Delta c_{1}^{-}=c_{1}^{\prime}-c_{0}-c_{1}^{\prime} k_{1}=c_{1}^{\prime}\left(1-k_{1}\right)-c_{0}=c_{1}^{\prime \prime}-c_{0} .
$$

If $v \geq 2$, we have

$$
\Delta c_{\nu}^{+}-\Delta c_{v}^{-}=c_{\nu}^{\prime}-c_{\nu-1}^{\prime \prime}-c_{\nu}^{\prime} k_{v}=c_{\nu}^{\prime}\left(1-k_{\nu}\right)-c_{\nu-1}^{\prime \prime} .
$$

Considering Eq. (4), Eq. (19) takes the following form:

$$
\Delta c_{v}^{+}-\Delta c_{v}^{-}=c_{v}^{\prime \prime}-c_{v-1}^{\prime \prime}
$$


Now, Eq. (17) can be expressed as

$$
M=q_{\mathrm{t}} \sum_{i=1}^{l}\left(c_{i}^{\prime \prime}-c_{i-1}^{\prime \prime}\right)+q_{\mathrm{a}} \sum_{j=1}^{m}\left(c_{j}^{\prime \prime}-c_{j-1}^{\prime \prime}\right)+q_{\mathrm{p}} \sum_{k=1}^{n}\left(c_{k}^{\prime \prime}-c_{k-1}^{\prime \prime}\right),
$$

where $c_{v-1}^{\prime \prime}=c_{0}$ if $v=1$. Hence, the formulas for $M$, obtained above, express the formation of pollution load in the facility with either direct (Eqs. (7), (9) and (10)) or consecutive (Eqs. (12) and (21)) systems of water supply. On the whole, since the domestic wastewater that is expressed by the third term of the algorithm does not contain PS under discussion, $M$ is determined by two members. It is evident, that in case of a combined system of water supply the algorithm is compiled on the basis of the above presented expressions in accordance with the real schemes of water consumption in the observed company.

\section{PRACTICAL APPLICATION OF THE ALGORITHM}

The value of $M$ (Eq. (3), for example) expresses the real waste discharge from the industry as mass flow. In the environmental management, the limiting value of this is called limiting permissible discharge $\left(D_{\mathrm{e}}\right)$. Consequently, equalizing the right side of Eq. (3) not with the real discharge $M$ but with its limit value $D_{\mathrm{e}}$, we obtain the limiting state equation for the discharge, generated by the plant:

$$
D_{\mathrm{e}}=\sum_{i=1}^{l} c_{i}^{\prime} q_{\mathrm{t} i}+\sum_{j=1}^{m} c_{j}^{\prime} q_{\mathrm{aj}}+\sum_{k=1}^{n} c_{k}^{\prime} q_{\mathrm{p} k}
$$

where the value $D_{\mathrm{e}}$ is often determined by a municipal environmental agency. On the other hand, $D_{\mathrm{e}}$ can be calculated from the well-known formula

$$
D_{\mathrm{e}}=C_{\mathrm{e}} q_{\mathrm{e}},
$$

where $C_{\mathrm{e}}$ is the limiting permissible concentration of PS in the industrial effluent $q_{\mathrm{e}}$, discharged into municipal sewerage or natural water body with its water quality standard $C$. In the first case the numerical value of $C_{\mathrm{e}}$ is taken from $\left[{ }^{13}\right]$ (if the PS is included there), if not, then $C_{\mathrm{e}}$ is determined with the help of Eq. (24) that is obtained as a result of complex standardization of the discharge of effluents into the municipal sewage system $\left[{ }^{14}\right]$. That means taking into account the level of dilution of the given PS in the municipal sewage system, the effect of its purification in the municipal wastewater treatment plant (MTP) as well as mixing the effluents with the water of the receiving water object:

$$
C_{\mathrm{e}}=\frac{(1-\alpha) q_{\mathrm{s}}}{(1-k) q_{\mathrm{e}}} c_{\mathrm{s}}^{\prime \prime}
$$


where $q_{\mathrm{s}}$ is the flow rate of the sewage water conveyed to MTP, $q_{\mathrm{e}}$ is the flow rate of wastewater, discharged into the municipal sewage, $\alpha$ is the content coefficient of PS in wastewater $q\left(q=q_{\mathrm{s}}-q_{\mathrm{e}}\right), k$ is the treatment coefficient of PS at MTP and $c_{\mathrm{s}}^{\prime \prime}$ is the normalized concentration of PS in the purified municipal wastewater $q_{\mathrm{s}}$, calculated from Eq. (25) or (26). In many countries the water user must have a permit, where the limit values of discharge $(D)$ for the pollutants are given. In such cases the concentration of $c_{\mathrm{s}}^{\prime \prime}$ in Eq. (24) may be determined as

$$
c_{\mathrm{s}}^{\prime \prime}=\frac{D}{q_{\mathrm{s}}}
$$

where $q_{\mathrm{s}}$ is the flow rate of the municipal sewage water, treated in MTP and conveyed to a natural waterbody. In case the water quality in the water object is regulated with governmental standards $C$ (like, for example, in Russia) the value of $c_{\mathrm{s}}^{\prime \prime}$ is determined from the well-known formula $\left[{ }^{15}\right]$ :

$$
c_{\mathrm{s}}^{\prime \prime}=(n-1)\left(C-c_{\mathrm{b}}\right)+C,
$$

where $n=\left(\gamma Q+q_{\mathrm{s}}\right) / q_{\mathrm{s}}$ is the dilution share of municipal wastewater with receiving waters, $Q$ is the flow rate of the watercourse under consideration, $\gamma$ is the mixing factor $(0 \leq \gamma \leq 1)$ and $c_{\mathrm{b}}$ is the background concentration of PS in the waterbody. The above expressions of the PS formation algorithm include the actual flow rate of wastewater from the enterprise $q_{\mathrm{e}}$ or its components by unit operations $q_{\mathrm{ti}}, q_{\mathrm{aj}}$ and $q_{\mathrm{p} k}$. As shown in $\left.{ }^{12}\right]$, individual standards of water consumption and wastewater run-off are used to design the water management systems of industrial enterprises. These standards are denoted usually for one production unit as “*”. Thus it is possible to write

$$
Q_{\mathrm{e}}^{*}=Q_{\mathrm{t}}^{*}+Q_{\mathrm{a}}^{*}+Q_{\mathrm{p}}^{*}=\sum_{i=1}^{l} Q_{\mathrm{t} i}^{*}+\sum_{j=1}^{m} Q_{\mathrm{a} j}^{*}+\sum_{k=1}^{n} Q_{\mathrm{p} k}^{*},
$$

where $Q_{\mathrm{e}}^{*}$ is the specific flow-off standard of the company, related to unit production, $Q_{\mathrm{t}}^{*}, Q_{\mathrm{a}}^{*}$ and $Q_{\mathrm{p}}^{*}$ are specific individual effluent standards in accordance with the main water use directions t, a and $\mathrm{p}, Q_{\mathrm{ti}}^{*}, Q_{\mathrm{aj}}^{*}$ and $Q_{\mathrm{p} k}^{*}$ are specific individual effluent standards by the unit water use operations $i, j, k$ in accordance with the main water use directions, respectively. Now, in case of more stringent analysis it is expedient to replace the actual flow rates of the wastewater $q_{\mathrm{t} i}, q_{\mathrm{a} j}$ and $q_{\mathrm{p} k}$ with their specific normative values $Q_{\mathrm{t} i}^{*}, Q_{\mathrm{aj}}^{*}$ and $Q_{\mathrm{p} k}^{*}$ (Eq. (27)) in the above presented algorithm (in Eq. (22), for example). Thus Eq. (22) can be written as a limiting state equation of the algorithm, related to the unit product, as

$$
D_{\mathrm{e}}^{*}=\sum_{i=1}^{l} c_{i}^{\prime} Q_{\mathrm{t} i}^{*}+\sum_{j=1}^{m} c_{j}^{\prime} Q_{\mathrm{a} j}^{*}+\sum_{k=1}^{n} c_{k}^{\prime} Q_{\mathrm{p} k}^{*}
$$


where $D_{\mathrm{e}}^{*}$ may be called the specific limiting permissible discharge of PS (value related to the unit of production “*”). Now, considering Eq. (27), Eq. (28) can be written for the main water use directions as

$$
D_{\mathrm{e}}^{*}=c_{\mathrm{t}}^{\prime} Q_{\mathrm{t}}^{*}+c_{\mathrm{a}}^{\prime} Q_{\mathrm{a}}^{*}+c_{\mathrm{p}}^{\prime} Q_{\mathrm{p}}^{*}=c_{\mathrm{e}}^{\prime} Q_{\mathrm{e}}^{*},
$$

where $c_{\mathrm{t}}^{\prime}, c_{\mathrm{a}}^{\prime}$ and $c_{\mathrm{p}}^{\prime}$ are concentrations of PS in the total effluent of the water use directions $\mathrm{t}$, a and $\mathrm{p}$, respectively and $c_{\mathrm{e}}^{\prime}$ is the concentration of PS in the total effluent of the enterprise. On the other hand, on the basis of Eq. (23) we can write

$$
D_{\mathrm{e}}^{*}=Q_{\mathrm{e}}^{*} C_{\mathrm{e}},
$$

where the limiting concentration $C_{\mathrm{e}}$ in the total effluent of the company $Q_{\mathrm{e}}^{*}$ should be calculated from Eq. (24). Using Eq. (22), it may be said that the effluent formation process is controlled by one parameter - by the limiting concentration of PS, i.e. by $C_{\mathrm{e}}$ (Eq. (23)), but using Eq. (28) - by two parameters: the normalized concentration $C_{\mathrm{e}}$ and the flow-off standard $Q_{\mathrm{e}}^{*}$ (cf. Eq. (30)) or its components (cf. Eq. (27)). In case of environmental impact assessment of waste effluents, if the right side of the limiting state equation (e.g. Eq. (22)) is smaller or equal to the left side (limiting discharge $D_{\mathrm{e}}$ or its specific value $D_{\mathrm{e}}^{*}$ as represented in Eq. (28)), the company may be classified relative to its wastewater as environmentally friendly. In the opposite case, if $M>D_{\mathrm{e}}$, it is evident that the environmental challenge to the company exists minimization of its own environmental impact by generating less waste (to generate less harmful substances with its wastewater). The normative value $D_{\text {e }}$ or its specific value $D_{\mathrm{e}}^{*}$ can be realized in practice if a number of technological and water management measures are implemented inside the plant. In the stage of development of water management measures it is accepted first to compare the real flow-off rate $q_{\mathrm{e}}\left(q_{\mathrm{e}}^{*}\right)$ of the plant with its flow-off standard $Q_{\mathrm{e}}\left(Q_{\mathrm{e}}^{*}\right)$. If $q_{\mathrm{e}}>Q_{\mathrm{e}}$ or $q_{\mathrm{e}}^{*}>Q_{\mathrm{e}}^{*}$, it is generally reasonable to compare the real water consumption $q_{\mathrm{c}}\left(q_{\mathrm{c}}^{*}\right)$ of the company with its water consumption standard $Q_{\mathrm{c}}$ $\left(Q_{\mathrm{c}}^{*}\right)$ beacause, in general, the wastewater run-off of an enterprise is in correlation with the water consumption. The author's practice in this area shows that in 11 major plants in Tallinn the real water consumption need was almost always up to $18 \%$ bigger than the designed standards. To clarify why it is so it is necessary to analyse the water consumption by single operations and whether it is necessary to go down to the level of separate water-using unit processes, i.e. to the differential level of the analysis. Thus these areas of the production process, which use water over the standard value, can be found out. If water consumption in these production stages is decreased by applying special measures (technological or water management), a decrease in the waste load of the PS can be achieved. 


\section{CONCLUSIONS}

Environmental impact assessment of the industrial enterprises has become an important part of contemporary environment protection. This paper presents an algorithm for the formation of the waste load of pollutants in industrial effluents. While compiling the algorithm, two main schemes of industrial water consumption were used, the direct and the consecutive one. Water consumption is characterized in all three basic directions (technological, auxiliary-subsidiary and domestic-potable) and their separate unit operations. The discharged water (flowoff) follows the same directions and unit processes, accordingly. Taking into account the possible dilution of effluents both in the sewer and in the receiving waterbody as well as the treatment effect of pollutants at the treatment plant, the limit status equation of the algorithm is compiled. The analysis of the latter enables the assessment of the environmental impact of the effluents for the whole company (integral level of analysis) and for single unit operations (differential level of analysis). Namely, if the real discharge of the pollutant under discussion is smaller or equal to the normalized discharge, the plant may be classified as an environmentally friendly organization. In the opposite case the environmental challenge to the company exists - to decrease the pollution load of the wastewater. Thus the company may apply a more detailed environmental impact assessment of its effluents and, finally, develop internal measures for improving its environmental performance. The analysis, suggested in the present article, represents a part of a more profound environmental impact assessment that may be used together with product life cycle analysis.

\section{REFERENCES}

1. Welford, R. and Gouldson, A. Environmental Management and Business Strategy. Pitman, London, 1991.

2. Antila, P., Ojanen, M., Puhakka, M., Vuorisalo, T. and Frey, T. Globaalsed keskkonnaprobleemid. Eesti Loodusfoto, Tartu, 1996.

3. Le Planetoscope: histoire et avenir écologique de la Terre (sous la direction d'Antoine Reillé). Dunod, Paris, 1992.

4. Lémeshev, M. Désastre écologique en URSS (les ravages de la bureaucratie). Eyrolles, Paris, 1991.

5. Environmental Priority Action Programme for Leningrad, Leningrad Region, Karelia and Estonia. Synthesis Report, Ministry of the Environment of Finland, Helsinki, 1991.

6. Laskorin, B. N., Bolotina, O. T. and Kaminskij, V. S. Quality and protection of the water in River Volga. Vodnye resursy, 1975, 4, 82-89 (in Russian).

7. Turbas, E. See ohtlik tolmusaaste. Eesti Loodus, 1991, 3, 142-144.

8. Ida-Virumaa District. In Human Impact on Environment. Estonian Academy of Sciences, Tallinn, 1991, 8-9.

9. Ehrlich, P. and Ehrlich, A. The Population Explosives. Arrow, London, 1991.

10. Encyclopedia of Global Enviornmental Change. Causes and Consequences of Global Environmental Change. Vol. 3 (Douglas, I., ed.). J. Wiley, Manchester, 2002. 
11. Talve, S. Feasibility and Limitation of Applying Life Cycle Assessment in Estonia. Doctoral Thesis, Helsinki University of Technology, Department of Forest Products Technology, Espoo, 2001.

12. Methodological Bases for the Elaboration of the Rules and Standards for Water Consumption and Discharge Taking into Account the Quality of the Used and Discharged Industrial Water. Nauchno-issledovatel'skij institut planirovaniya i normativov, Moscow, 1979 (in Russian).

13. Ühisveevärgi ja -kanalisatsiooni seadus. Riigi Teataja, RT I 1999, 25, 363.

14. Säärekõnno, J. De l'établissement complexe des normes pour le déversement des substances polluantes dans l'environment aqueux. Tr. Tallinsk. politekhn. inst., 1989, 686, 60-67 (in Russian).

15. Rodziller, I. D. Limiting permissible discharges of the polluting substances. Vodosnabzhenie $i$ sanitarnaya tekhnika, 1986, 2, 11-13 (in Russian).

\title{
Tööstusheitvetes sisalduva reostuskoormuse kujunemise algoritm
}

\begin{abstract}
Jüri Säärekõnno
Tööstusettevõtete keskkonnamõjude hindamine on kujunenud kaasaegse keskkonnakaitse oluliseks osaks. Tööstusreovetest põhjustatud keskkonnamõjude paremaks hindamiseks on antud töös esitatud ettevõtte reoveega formeeruva reoaine arvutamise algoritm. Lähtudes reoaine kompleksse normeerimise printsiibist, st võttes arvesse reoaine võimalikku lahjendust nii veekogus kui ka asula kanalisatsioonis, samuti asula reoveepuhasti efekti vaadeldava reoaine suhtes, on koostatud reovee piirseisundi võrrand. Viimase lahendid määravad vee kvaliteedile esitatavad nõuded ning võimaldavad analüüsida ja hinnata ettevõtte reovete keskkonnamõjusid nii integraalselt (ettevõttes tervikuna) kui ka diferentseeritult (ettevõtte veekasutuse üksikoperatsioonide tasandil).
\end{abstract}

